\section{Timing and K-IBA Treatments Affect Rooting of Stem Cuttings of Cephalotaxus harringtonia}

\author{
Andrea L. Southworth ${ }^{1}$ and Michael A. Dirr ${ }^{2}$ \\ Department of Horticulture, University of Georgia, Athens, GA 30602
}

Additional index words. Japanese plum yew, timing, vegetative propagation, auxin

Abstract. Stem cuttings from a prostrate clone of Cephalotaxus harringtonia (Forbes) K. Koch (Japanese plum yew) were taken monthly from Sept. 1994 through Aug. 1995,

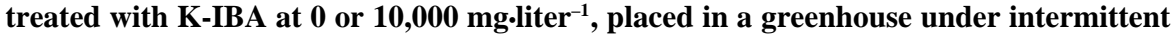
mist, and evaluated after 16 weeks. Cuttings taken from December to February and treated with K-IBA averaged $85 \%$ rooting, 10 roots per cutting, and a total root length of $35 \mathrm{~cm}$. The next highest rooting percentages were for cuttings taken from March to May; poorest rooting occurred for cuttings taken from June to August and September to November, regardless of K-IBA application. Chemical name used: K-indole-3-butyric acid (K-IBA).

Cephalotaxus harringtonia and its botanical varieties and cultivars offer unlimited landscape potential for U.S. Dept. of Agriculture (USDA) hardiness zones 5 through 8 (USDA, 1990). Plants are heat and drought tolerant and sun and shade adaptable and resist deer browsing (Dirr, 1990; Tripp, 1994). Consumer demand for these taxa has increased steadily in the past 3 years. In 1994, the low-growing forms $(C$. harringtonia var. drupacea and 'Prostrata') were named as Georgia Gold Medal Award recipients, which resulted in depletion of nursery inventory in Georgia. In addition, demand for plants exists because $C$. harringtonia contains alkaloids with antitumor activities (Delfel and Rothfus, 1977; Perdue et al., 1970; Powell et al., 1972).

Plants can be propagated by seeds (Creech, 1986; Dirr and Heuser, 1987), although seeds are not readily available and germination requirements are not well defined. Asexual propagation by tissue culture has been reported but has emphasized alkaloid production and not plant regeneration (Delfel, 1980; Delfel and Rothfus, 1977; Wickremesinhe and Arteca, 1991). Wickremesinhe and Arteca (1993) regenerated plantlets from callus cultures but reported low establishment $(<5 \%)$. Janick et al. (1994) successfully propagated plants from zygotic embryos cultured in vitro; however, this approach does not ensure phenotypic uniformity. Stem cutting propagation of $C$. harringtonia is not well defined, although most plants are propagated by cuttings (Dirr, 1992; Tripp, 1994). Tripp (1994) re-

\footnotetext{
Received for publication 17 Apr. 1995. Accepted for publication 6 Oct. 1995. Research conducted at The Univ. of Georgia, Athens. Use of trade names does not imply endorsement of the products named nor criticism of similar ones not named. The cost of publishing this paper was defrayed in part by the payment of page charges. Under postal regulations, this paper therefore must be hereby marked advertisement solely to indicate this fact.

${ }^{1} \mathrm{MS}$ graduate.

${ }^{2}$ Professor.
}

ported that stem cuttings can be rooted yearround, except during the spring growth flush period, with or without auxin treatment. Rooting percentages of mid-March cuttings treated with indole-3-butyric acid (IBA) as a talc formulation and nontreated cuttings were similar (Dirr and Heuser, 1987). According to commercial growers, rooting may take $\geq 6$ months, and plants often develop slowly because of sparse root systems. Producing a salable plant often takes 2 to 3 years (Tripp, 1994). This study was initiated to determine the effects of timing and auxin treatment on the rooting of $C$. harringtonia stem cuttings.

\section{Materials and Methods}

Eighty, terminal, 15-cm-long cuttings of C. harringtonia were taken monthly, from 15 Sept. 1993 through 15 Aug. 1994, from a prostrate clone growing on the campus of The Univ. of Georgia, Athens. Cuttings were pruned to a $10-\mathrm{cm}$ length, and needles were removed from the basal half of the stem. Half the cuttings were dipped to a $2.5-\mathrm{cm}$ depth for 5 $\mathrm{sec}$ in K-IBA at $10,000 \mathrm{mg} \cdot \mathrm{liter}^{-1}$ in water, while the remaining were not treated (control).
Bases of the cuttings were air-dried for $20 \mathrm{~min}$ before insertion into cells $(7.62 \times 7.62 \times 7.94$ $\mathrm{cm})$ filled with a 3 perlite : 1 peat $(\mathrm{v} / \mathrm{v})$ medium. Cuttings were maintained under natural photoperiods and irradiance with 30C day/ $21 \mathrm{C}$ night. Intermittent mist operated daily 2.5 sec every 5 min from 8:30 AM until 6:00 PM. Misting was extended in the summer to compensate for longer days. Bottom heat $(21 \pm 3 \mathrm{C})$ was provided from December through March. A completely randomized design was used with five replications per treatment and eight cuttings per replication. Rooting percentages, number of roots, and root lengths were determined after 16 weeks. Roots $\geq 5 \mathrm{~mm}$ in length were included in the data, and a cutting having one or more root(s) was classified as rooted. Data were grouped into four 3-month periods (seasons) because there were seasonal trends in rooting responses. Significant differences between the nontreated and K-IBA treatments were tested for each season. Data were subjected to analysis of variance procedures.

\section{Results and Discussion}

Timing and K-IBA treatments affected rooting of $C$. harringtonia (Table 1). Cuttings taken in December to February and treated with K-IBA had significantly higher percent rooting (PR), mean number of roots (NR), and mean total root lengths (TRL) than the nontreated cuttings. These cuttings also had the highest PR, NR, and TRL compared to the other seasons and treatment. Cuttings taken in March to May and treated with K-IBA had significantly higher NR than the nontreated cuttings, although there were no significant differences in PR and TRL. The March to May control cuttings had five roots per cutting and $13 \mathrm{~cm}$ TRL. PR, although not significantly different from K-IBA-treated cuttings, was $11 \%$ higher. To our knowledge, effects of IBA and K-IBA on the rooting of Cephalotaxus taxa have not been clearly documented (Dirr and Heuser, 1987; Tripp, 1994). The inconsistencies in rooting response are possibly related to the season when the cuttings were taken. In this study, cuttings were responsive to exogenous K-IBA application in December to February and to a lesser degree in March to
Table 1. The effects of timing and K-IBA $\left(10,000 \mathrm{mg} \cdot \mathrm{liter}^{-1}\right)$ on rooting percentage, root count, and root length of Cephalotaxus harringtonia stem cuttings.

\begin{tabular}{|c|c|c|c|c|}
\hline \multirow[b]{2}{*}{ K-IBA } & \multicolumn{4}{|c|}{ Season } \\
\hline & $\begin{array}{l}\text { September to } \\
\text { November }\end{array}$ & $\begin{array}{c}\text { December to } \\
\text { February }\end{array}$ & $\begin{array}{c}\text { March to } \\
\text { May }\end{array}$ & $\begin{array}{l}\text { June to } \\
\text { August }\end{array}$ \\
\hline \multicolumn{5}{|c|}{ Rooting (\%) } \\
\hline - & 30.0 & 21.8 & 78.3 & 55.8 \\
\hline \multirow[t]{2}{*}{+} & 34.2 & 84.9 & 66.7 & 0.8 \\
\hline & NS & $* * *$ & NS & $* * *$ \\
\hline \multicolumn{5}{|c|}{ Mean number roots } \\
\hline - & 1.6 & 2.3 & 4.9 & 3.5 \\
\hline \multirow[t]{2}{*}{+} & 3.6 & 10.0 & 7.8 & 0.2 \\
\hline & NS & $* * *$ & $* * *$ & $* * *$ \\
\hline \multicolumn{5}{|c|}{ Mean total root length $(\mathrm{cm})^{z}$} \\
\hline - & 2.7 & 6.1 & 13.1 & 9.7 \\
\hline \multirow[t]{2}{*}{+} & 6.0 & 35.0 & 14.4 & 0.5 \\
\hline & NS & $* * *$ & NS & $* * *$ \\
\hline
\end{tabular}

${ }^{2}$ Means are per rooted cutting

NS, ${ }^{* * *}$ Nonsignificant or significant at $P \leq 0.001$. 
May. In September to November, treatment effects were nonsignificant. However, K-IBA treatment significantly reduced rooting in June to August. The June to August cuttings were soft and were maintained as terminal cuttings, even when new growth was present. Although K-IBA dissolved in water is generally less injurious to cuttings than the free acid of IBA dissolved in an organic solvent, the 10,000- mg.liter ${ }^{-1}$ rate induced basal necrosis on most cuttings. In retrospect, a lower $\mathrm{K}$-IBA rate may have been noninjurious and stimulatory.

The June to August and September to November cuttings that rooted never attained the quality standards (i.e., NR and TRL) of the December to February and March to May cuttings (Table 1). Low-temperature preconditioning has improved the rooting of many gymnosperms, including Abies Miller (fir) (Dirr and Heuser, 1987). The December to February cuttings and the March to May cuttings rooted in 10 to 12 weeks. It is possible the nontreated cuttings from June to August and September to November may have rooted if given more time. Growers report sticking cuttings in summer and waiting 12 months or longer for complete rooting. Nontreated and treated (IBA talc at 8000 and 20,000 mg.liter ${ }^{-1}$ ) mid-March cuttings of Cephalotaxus harringtonia 'Duke Gardens' rooted 63\%, $70 \%$, and $73 \%$, respectively, when examined 2 years later (Dirr and Heuser, 1987). 'Duke Gardens' cuttings taken in late September and treated with K-IBA at $3000 \mathrm{mg} \cdot \mathrm{liter}^{-1}$ failed to root by April, although they were in excellent condition.

The taxonomy of Cephalotaxus species and cultivars is confusing (Tripp, 1994). Differences possibly exist in the rooting responses of the various taxa. Based on our work with the low-growing clone of $C$. harringtonia, cuttings should be taken in December to February or March to May and treated with K-IBA at 10,000 mg.liter ${ }^{-1}$.

\section{Literature Cited}

Creech, J.L. 1986. Cephalotaxus and Podocarpus look for bigger roles in western gardens. Amer. Nurseryman 163(2):63-65.

Delfel, N.E. 1980. The effect of nutritional factors on alkaloid metabolism in Cephalotaxus harringtonia tissue cultures. Planta Medica 39:168-179.

Delfel, N.E. and J.A. Rothfus. 1977. Antitumor alkaloids in callus cultures of Cephalotaxus harringtonia. Phytochemistry 16:15951598.

Dirr, M.A. 1990. Manual of woody landscape plants: Their identification, ornamental characteristics, culture, propagation and uses. 4th ed. Stipes, Champaign, Ill.

Dirr, M.A. 1992. Cephalotaxus harringtonia, the Japanese plum yew: Superbly tolerant of heat, drought, sun and cold dipping to -15 to $-20^{\circ}$. Nursery Manager 8(4):24-25.

Dirr, M.A. and C.W. Heuser, Jr. 1987. The reference manual of woody plant propagation: From seed to tissue culture. Varsity Press, Athens, Ga.

Janick, J., A. Whipkey, S.L. Kitto, and J. Frett. 1994 Micropropagation of Cephalotaxus harringtonia. HortScience 29:120-122.

Perdue, R.E., Jr., L.A. Spetzman, and R.G. Powell 1970. Cephalotaxus - Source of harringtonine, A promising new anti-cancer alkaloid. Amer. Hort. Mag. 49:19-22.

Powell, R.G., D. Weisleder, and C.R. Smith, Jr 1972. Antitumor alkaloids from Cephalotaxus harringtonia: Structure and activity. J. Pharmaceutical Sci. 61:1227-1230.

Tripp, K.E. 1994. A plum yew primer. Amer. Nurseryman 180(9):28-37.

U.S. Dept. of Agriculture. 1990. USDA plant hardiness zone map. Misc. Publ. 1474. Government Printing Office, Washington, D.C.

Wickremesinhe, E.R. and R.N. Arteca. 1991. Organogenesis from Cephalotaxus harringtonia callus: Establishment of shoots and root cultures. HortScience 26:479. (Abstr.)

Wickremesinhe, E.R. and R.N. Arteca. 1993. Establishment of fast-growing callus and root cultures of Cephalotaxus harringtonia. Plant Cell Rpt. 12:80-83. 